\title{
Genome-wide Expression Profiling (with Focus on the Galectin Network) in Tumor, Transition Zone and Normal Tissue of Head and Neck Cancer: Marked Differences Between Individual Patients and the Site of Specimen Origin
}

\author{
VERONIKA ZIVICOVA ${ }^{1,2^{*}}$, PETR BROZ ${ }^{3 *}$, ZDENEK FIK ${ }^{1,2}$, ALZBETA MIFKOVA ${ }^{1,2}$, \\ JAN PLZAK ${ }^{2}$, ZDENEK CADA $^{2}$, HERBERT KALTNER ${ }^{4}$, JANA FIALOVA KUCEROVA ${ }^{3}$, \\ HANS-JOACHIM GABIUS ${ }^{4}$ and KAREL SMETANA JR. ${ }^{1,5}$ \\ ${ }^{1}$ Institute of Anatomy, and ${ }^{2}$ Department of Otorhinolaryngology, Head and Neck Surgery, \\ First Faculty of Medicine, Charles University, Prague, Czech Republic; \\ ${ }^{3}$ Institute of Applied Biotechnologies, Prague, Czech Republic; \\ ${ }^{4}$ Institute of Physiological Chemistry, Faculty of Veterinary Medicine, \\ Ludwig Maximilian University, Munich, Germany; \\ ${ }^{5}$ BIOCEV, First Faculty of Medicine, Charles University, Vestec, Czech Republic
}

\begin{abstract}
Background/Aim: Expression profiling was performed to delineate and characterize the impact of malignancy by comparing tissues from three sites of head and neck cancer of each patient, also determining interindividual variability. Materials and Methods: Genome-wide analysis was carried out covering the expression of 25,832 genes with quantification for each site of seven patients with tonsillar or oropharyngeal squamous cell carcinoma. Immunohistochemical analysis was performed for adhesion/growthregulatory galectins, three pro-inflammatory chemo- and cytokines and keratins. Results: Up-and down-regulation was found for 281 (tumor vs. normal) and 276 genes (transition zone vs. normal), respectively. The profile of the transition zone had its own features, with similarity to the tumor. Galectins were affected in a network manner, with differential regulation and interindividual variability between patients, also true for keratins and the chemo- and cytokines. Conclusion: These results underline special features at each site of specimen origin as well as the importance of analyzing galectins as a network and of defining the expression status of the individual patient prior to reaching clinically relevant conclusions.
\end{abstract}

\footnotetext{
*These Authors contributed equally to this study.

Correspondence to: Karel Smetana Jr., Institute of Anatomy, 1st Faculty of Medicine, Charles University, U Nemocnice 3, 12800 Prague 2, Czech Republic. E-mail: karel.smetana@1f1.cuni.cz
}

Key Words: Adhesion, glycosylation, lectin, malignancy, proliferation.
Squamous cell carcinoma (SCC) of the head and neck continues to be a major clinical challenge (1). This tumor type is characterized by locally aggressive growth, lymph node metastasis and limited spread beyond lymph nodes (2). Radical surgery represents the main therapeutic modality but can have unfavorable consequences and reduce quality of life. Clinically, reliable independent prognostic factors can guide decisions on the strategy of therapy for the individual patient. While classical parameters such as site of tumor localization, radicality of resection and human papillomavirus status have reached a high degree of validity, current research aims to identify molecular markers reflecting potential for tumor invasiveness and spread $(3,4)$. Delineating and studying functionally-relevant epitopes based on a clear concept thus offers the prospect of defining functional markers whose strategic blocking or regulation is innovative and may be of therapeutic benefit. The complexity of cellular glycosylation of lipids and proteins, amenable to analysis in molecular detail by sophisticated techniques and known to be like a fingerprint for cells $(5,6)$, and its capacity to store information at high coding capacity (7-10) provide an incentive towards this end.

In fact, the functional pairing of glycan determinants with endogenous receptors (lectins) is being revealed to be of broad (patho)physiological significance (11-13). Figuring prominently as contact sites, the termini of glycan chains are special due to their intimately regulated profiles of expression, e.g. by a tumor suppressor which eventually causes lectintriggered anoikis $(14,15)$. Such signals are evidently read and interpreted by members of the family of adhesion/growth- 
regulatory galectins (16-18), and these bioeffectors are present in SCC. Their study was initiated in cells and immunohistochemically for galectins 1 and 3 (19-24), then extended to other family members such as galectins 7,8 and 9 , indicating the presence of a galectin network (25-31). At the level of cellular activity, the demonstration that a lectin such as galectin-1 is associated to pro-inflammatory/invasive activities such as those of chemo- and cytokines, or the prodegradative matrix metalloproteinases, points to a molecular bridge from lectins to tumor progression (32-34). These results explain the interest in monitor immune mediators such as the chemokine (C-X-C motif) ligand 1 (CXCL1) and interleukin 6 and 8 (IL6/IL8), flanked by markers of differentiation, that are keratins $(35,36)$, concomitantly with studying the galectin network in this tumor class. The work here feared on the level of such factors in individual patients in genome-wide expression analysis, and for specimens from three different regions of each patient.

In this study, we address two issues. In the first step, we performed a genome-wide expression analysis of the tumor (SCC), the margin of surgical resection (MSR) and normal tissue (NOE) to comparatively map the influence of the site on mRNA representation. Next, mRNA quantity for seven members of the galectin family was determined, together with that for seven keratins and the three immune factors for each patient in order to characterize interindividual variability. Finally, this network analysis was taken to the level of immunohistochemistry for selected probes to visualize distribution profiles of the gene products. The observed differences between signal intensities at the mRNA level of and immunopositivity substantiate interpretation of each set of data in its own context without unwarranted extrapolations.

\section{Materials and Methods}

Characteristics of patients and tissue processing. Samples were collected from patients suffering from SCC after acquiring their informed consent and study design approval by the Local Ethical Committee of the University Hospital in Motol, Prague, Czech Republic No. MZ VES 2015, in agreement with the Declaration of Helsinki. The characteristics of patients are summarized in Table I. For each case, specimens of each of the three tissue regions, i.e. SCC, MSR and NOE from the contralateral cheek of each donor, were processed. Tissue specimens were routinely incubated in RNAlater ${ }^{\circledR}$ (Ambion, Foster City, CA, USA) to preclude degradation by activity of endogenous RNases, frozen in liquid nitrogen and stored at $-80^{\circ} \mathrm{C}$. Frozen sections ( $7 \mu \mathrm{m}$ thickness) were prepared using CryoCut-E (Reichert-Jung, Vienna, Austria) and used for extraction of RNA and for immunohistochemistry.

RNA Extraction and library preparation for sequencing. Total RNA from 30 microdissected cryosections of each sample stored in RNAlater was isolated using the reagents of the RNeasy Micro Kit (Qiagen, Hilden, Germany) according to manufacturer's instructions, including DNase I treatment. The concentration of
Table I. Characteristics of studied patients.

\begin{tabular}{lcc}
\hline & \multicolumn{2}{c}{ Tumor localization, $\mathrm{n}$} \\
\cline { 2 - 3 } Characteristic & Tonsil (n=6) & Oropharynx (n=1) \\
\hline Gender, $\mathrm{n}$ & & \\
Male & 6 & 0 \\
Female & 0 & 1 \\
Mean age & 61 & 68 \\
T Classification, $\mathrm{n}$ & & \\
T2 & 5 & 1 \\
T3 & 1 & 0 \\
N Classification, $\mathrm{n}$ & & 0 \\
N0 & 1 & 0 \\
N1 & 1 & 0 \\
N2 & 2 & 0 \\
N2b & 1 & 1 \\
N2c & 1 & 1 \\
M Classification, $n$ & & \\
M0 & 6 & \\
\hline
\end{tabular}

RNA was measured with a Qubit 3.0 fluorimeter (Life Technologies, Carlsbad, CA, USA), and its quality was routinely determined by 2100 Bioanalyzer and RNA 6000 Nano kit reagents (Agilent, Santa Clara, CA, USA). A sequencing library including indices was prepared in two pools using a TruSeq Stranded mRNA LT Sample Prep Kit (Illumina, San Diego, USA). The cDNA concentration of the libraries was measured using the KAPA Library Quantification Kit (Kapa Biosystems, Wilmington, MA, USA), the size distribution was estimated by Agilent High Sensitivity DNA Kit reagents and 2100 Bioanalyzer equipment (Agilent). Clusters were generated with TruSeq Rapid Cluster Kit/cBot (Illumina) on two separate rapid flow lines using $10 \mathrm{pM}$ diluted libraries, with $1 \%$ PhiX control added. Sequencing on an Illumina Hiseq 2500 instrument was performed to generate $2 \times 50$-bp paired-end exome reads using TruSeq Rapid SBS Kit chemistry.

Overview of primary analysis. Material from the 21 different samples from seven patients (SCC, MSR and NOE for each) was sequenced. A total of 109 cycles yielded $35.21 \mathrm{Gbp}$ of raw data with $96.65 \%$ clusters passing filter for read 1 and $97.71 \%$ for read 2 . The overall percentage of bases matching or being above the Q30 Illumina Sequencing Quality Score was $96.5 \%$, and cluster density reached optimal range for both reads with 1012 and $836 \mathrm{~K} / \mathrm{mm}^{2}$, respectively. Aligned reads for spiked PhiX control reached $0.92 \%$ of total.

Data pre-processing and RNA-seq alignment. The raw data (BCL files) were demultiplexed using Illumina's tool bcl2fastq (version 2.17; Illumina) with default parameters. The quality of raw FASTQ files was checked using the program MultiQC (37). All reads passed the quality control (Phred Qual Score $>30$ ). Reads of the length of 50 bases were aligned to human genome hg19 reference (https://support.illumina.com/sequencing/sequencing_software/igeno me.html) applying the splice junction mapper for RNA-seq reads TopHat (38). The default parameters for TopHat were used. The output was as a BAM file (39). 
Table II. List of antibodies used for immunohistochemistry.

\begin{tabular}{lccc}
\hline Primary antibody & Producer & Secondary antibody/fluorochrome & Producer \\
\hline Galectin-1/P & Munich laboratory (in house) & Swine anti-rabbit/FITC & DAKO Cytomation, Glostrup, Denmark \\
Galectin-3/P & & & \\
Galectin-4/P & & & \\
Galectin-7/P & & & Sigma-Aldrich, Prague, Czech Republic \\
Galectin-8/P & & & \\
Galectin-9/P & DAKO Cytomation, Glostrup, Denmark & Goat anti-mouse/TRITC (or FITC) \\
Keratin 8/M & & & \\
Keratin 19/M & Sigma-Aldrich, Prague, Czech Republic & & \\
Keratin 14/M & & & \\
Keratin 17/M & & & \\
CD45/M & & & \\
\hline
\end{tabular}

P: Rabbit polyclonal, M: mouse monoclonal, FITC: fluorescein isothocyanate, TRITC: tetramethylrhodamine isothiocyanate.

RNA-seq data quantification and gene expression. Analysis was performed by Tuxedo pipeline-based processing (40). The resultant BAM files were used in Cufflinks algorithm v 2.2.1 (39). Differential expression analysis was performed by Cuffdiff v. 2.2.1 (40) based on transcript abundances. The raw output cufflinks transcripts were $\log 2$ transformed at fragments per kilobase of exon per million mapped reads (FPKM). To avoid taking $\log 2$ of zero, we routinely added a constant $(0.01)$ to the FPKM.

Statistical analysis. Genome-wide comparisons were made to pinpoint significant differences and interindividual comparison of selected genes mentioned above (galectins, keratins and pro-tumoral chemo- and cytokines). Genes differentially expressed at a $\log 2$ fold-change value greater than 2 (based on FPKM ratio) and false discovery rates (FDR) values of less than $5 \%$ were listed. Gene ontology (GO) and pathway analysis of up- and down-regulated genes were performed using Enrichr and PANTHER (41) databases. Statistical analysis was carried out using the CummeRbund Bioconductor package within the R environment ( $\mathrm{R}$ Development Core Team 2007).

Immunohistochemistry. Tissue sections were routinely washed in phosphate-buffered saline (PBS; $\mathrm{pH}$ 7.2), fixed in 5\% paraformaldehyde in PBS for $5 \mathrm{~min}$ and extensively washed with PBS. The primary antibodies listed in Table II were diluted as recommended by the supplier or tested at 1:50 when made in-house, and the signal of immunohistochemical processing was visualized by fluorescein isothocyanate (FITC)- or tetramethylrhodamine isothiocyanate (TRITC)-labeled second-step antibodies, also diluted as recommended by the supplier (Table II). As a control for specificity, that is, to exclude antigen-independent reactions, the first-step antibody was either omitted from the protocol or replaced by an irrelevant antibody (same isotype for the monoclonals). The polyclonal antibodies to galectin were made in-house, their specificity being rigorously checked for absence of any crossreactivity among human galectins by enzyme-linked immunosorbent assay (ELISA)//western blotting and rounds of chromatographic affinity depletion of the respective $\mathrm{IgG}$ fraction using resinimmobilized lectin (42-45). Nuclei were counterstained by 4',6diamidine-2-phenylindol (DAPI) (Sigma-Aldrich, Prague, Czech Republic), and the specimens were mounted in Vectashield (Vector
Laboratories, Burlingame, CA, USA). The specimens were inspected, evaluated and files stored using a Nikon-Eclipse $90 \mathrm{i}$ microscope equipped with the computer-assisted image analysis system LUCIA 5.1 (Laboratory Imaging, Prague, Czech Republic) and a Vosskühler VDS CCD-1300 camera (VDS Vosskühler GmbH, Osnabrück, Germany).

\section{Results}

Differential gene-expression profiling. A total of 25,832 genes was covered by this profiling. When compared in detail, the expression profile of SCC significantly differed from that of NOE in 281 genes, and MSR from NOE in 276 genes. The most highly dysregulated gene products in SCC are listed in Table III (SCC vs. NOE; upregulated) and Table IV (SCC vs. NOE; down-regulated). For comparison, Table $\mathrm{V}$ and Table VI list the respective information on the MSR $v s$. NOE comparison, and Table VII and Table VIII complete the pairwise comparisons by presenting the results of setting MSR and SCC data in relation. The extended version of each listing is accessible at http://www.physiolchem.vetmed.unimuenchen.de/summary/anticancer_research/index.html

Various families of proteins appear in these lists (and the further identified cases), among them so-called glycogenes coding for lectins such as collectin-11, CD22 (siglec-2) and galectins or glycosyltransferases such as genes for $\beta-1,4-N$ acetyl-galactosaminyltransferase 4 (preparing the LacdiNAc epitope) or $\alpha 2,6$-sialyltransferase 1 , the main activity of $\alpha 2,6$ sialylation. As graphically illustrated in the heat map with the dendrogram based on Jensen-Shannon distances, the profiles of gene expression have distinctive features (Figure 1). Of interest, the profile of MSR was revealed to be different from that for NOE, as demonstrated by principal component analysis (PCA) for dimensionality reduction and by multidimensional scaling for dimensionality reduction (Figure 2). Using the gene ontology (GO) and pathway analysis, respective assignment of the most dysregulated cases of gene 
Table III. The genes most up-regulated in squamous cell carcinoma compared to normal epithelium.

\begin{tabular}{|c|c|c|c|c|}
\hline Gene symbol & HGNC & Ontology & Fold-change & $p$-Value \\
\hline KRT10 & 6413 & Keratin, type I cytoskeletal 10 & 7.28096 & 0.00005 \\
\hline CIDEC & 24229 & Cell death activator CIDE-3 & 7.20618 & 0.0005 \\
\hline KRT31 & 6448 & Keratin, type I cuticular Ha1 & 5.89646 & 0.00005 \\
\hline HHLA2 & 4905 & HERV-H LTR-associating protein 2 & 4.95419 & 0.00005 \\
\hline$L Y 6 G 6 C$ & 13936 & Lymphocyte antigen 6 complex locus protein G6c & 4.87151 & 0.0006 \\
\hline PLAC9 & 19255 & Placenta-specific protein 9 & 4.57599 & $3.50 \mathrm{E}-004$ \\
\hline KRTDAP & 16313 & Keratinocyte differentiation-associated protein & 4.47024 & $5.00 \mathrm{E}-005$ \\
\hline$C R N N$ & 1230 & Cornulin & 4.35129 & $6.00 \mathrm{E}-004$ \\
\hline IL18 & 5986 & Interleukin-18 & 3.23351 & $5.00 \mathrm{E}-005$ \\
\hline COX7A1 & 2287 & Cytochrome c oxidase subunit 7A1, mitochondrial & 4.31603 & $5.00 \mathrm{E}-005$ \\
\hline CD36 & 1663 & Platelet glycoprotein 4 & 4.3085 & $5.00 \mathrm{E}-005$ \\
\hline MTRNR2L10 & 37167 & Humanin-like 10 & 4.20429 & $2.50 \mathrm{E}-004$ \\
\hline$L C E 3 D$ & 16615 & Late cornified envelope protein $3 \mathrm{D}$ & 4.18008 & $5.00 \mathrm{E}-005$ \\
\hline$P L A 2 G 2 A$ & 9031 & Phospholipase A2, membrane associated & 4.044 & $5.00 \mathrm{E}-005$ \\
\hline$M A L$ & 6817 & Myelin and lymphocyte protein & 3.97912 & $5.00 \mathrm{E}-005$ \\
\hline$M I R 17 H G$ & 23564 & Putative microRNA 17 host gene protein & 3.77539 & $5.00 \mathrm{E}-005$ \\
\hline$C N F N$ & 30183 & Cornifelin & 3.76645 & $2.50 \mathrm{E}-004$ \\
\hline ALOX12 & 429 & Arachidonate 12 -lipoxygenase, $12 \mathrm{~S}$-type & 3.75755 & $5.00 \mathrm{E}-005$ \\
\hline$D C L K 1$ & 2700 & Serine/threonine-protein kinase DCLK1 & 3.71979 & 2.50E-004 \\
\hline HSPB 6 & 26511 & Heat shock protein $\beta 6$ & 3.61402 & $5.00 \mathrm{E}-005$ \\
\hline KRT3 & 6440 & Keratin, type II cytoskeletal 3 & 3.59278 & $5.00 \mathrm{E}-005$ \\
\hline
\end{tabular}

HGNC: Human Gene Nomenclature Committee.

Table IV. The genes most down-regulated in squamous cell carcinoma compared to normal epithelium.

\begin{tabular}{|c|c|c|c|c|}
\hline Gene symbol & HGNC & Ontology & Fold-change & $p$-Value \\
\hline$S P P 1$ & 11255 & Osteopontin & -8.01172 & $2.00 \mathrm{E}-004$ \\
\hline$M Z B 1$ & 30125 & Marginal zone B- and B1-cell-specific protein & -5.9354 & $5.00 \mathrm{E}-005$ \\
\hline IGLL5 & 38476 & Immunoglobulin $\lambda$-like polypeptide 5 & -5.75518 & $5.00 \mathrm{E}-005$ \\
\hline$C L C$ & 2014 & Galectin-10 & -5.71586 & $5.77 \mathrm{E}-002$ \\
\hline STAG3 & 11356 & Cohesin subunit SA-3 & -5.56316 & $2.50 \mathrm{E}-004$ \\
\hline DERL3 & 14236 & Derlin-3 & -5.54659 & $5.00 \mathrm{E}-005$ \\
\hline SERPINE1 & 8583 & Plasminogen activator inhibitor 1 & -5.00641 & $5.00 \mathrm{E}-005$ \\
\hline$A L G 1 L$ & 33721 & Putative glycosyltransferase ALG1-like & -4.99979 & $2.00 \mathrm{E}-004$ \\
\hline PRR4 & 18020 & Proline-rich protein 4 & -4.81877 & $5.00 \mathrm{E}-005$ \\
\hline COLEC11 & 17213 & Collectin-11 & -4.78257 & $5.50 \mathrm{E}-004$ \\
\hline PTHLH & 9607 & Parathyroid hormone-related protein & -4.28194 & $5.00 \mathrm{E}-005$ \\
\hline$M M P 11$ & 7157 & Stromelysin-3 & -4.28087 & $5.00 \mathrm{E}-005$ \\
\hline PTGS2 & 9605 & Prostaglandin $\mathrm{G} / \mathrm{H}$ synthase 2 & -4.2221 & $5.00 \mathrm{E}-005$ \\
\hline IL6 & 6018 & Interleukin-6 & -4.12237 & $2.54 \mathrm{E}-002$ \\
\hline$C D 79 A$ & 1698 & B-Cell antigen receptor complex-associated protein $\alpha$-chain & -4.09462 & $5.00 \mathrm{E}-005$ \\
\hline MEI1 & 28613 & Meiosis inhibitor protein 1 & -4.09113 & $5.00 \mathrm{E}-005$ \\
\hline$U B D$ & 18795 & Ubiquitin D & -3.95711 & $5.00 \mathrm{E}-005$ \\
\hline$L A M C 2$ & 6493 & Laminin subunit $\gamma 2$ & -3.93688 & $5.00 \mathrm{E}-005$ \\
\hline AIM2 & 357 & Interferon-inducible protein AIM2 & -3.81255 & $5.00 \mathrm{E}-005$ \\
\hline$C D K N 2 A$ & 1787 & Cyclin-dependent kinase inhibitor $2 \mathrm{~A}$ & -3.57499 & $5.00 \mathrm{E}-005$ \\
\hline
\end{tabular}

HGNC: Human Gene Nomenclature Committee.

expression in SCC in relation to NOE was performed, with indications for extracellular sites of action (Table IX).

Based on the reasoning given in the introduction, data on galectins, keratins and cytokines are presented on a patientto-patient basis. Levels of gene expression of galectins-1, -
$2,-4,-8$ and -9 show increases in tumors relative to NOE, with the highest difference seen in the case of galectin- 4 (Figure 3A). However, individual cases showed exceptional data, i.e. a decrease. The same trends were seen for MSR data when compared to those for NOE (Figure 3B). The level 
Table V. The genes most up-regulated in margin of surgical resection compared to normal epithelium.

\begin{tabular}{|c|c|c|c|c|}
\hline Gene symbol & HGNC & Ontology & Fold-change & $p$-Value \\
\hline PRR4 & 18020 & Proline-rich protein 4 & 9.06544 & 0.00005 \\
\hline IGLL5 & 38476 & Immunoglobulin $\lambda$-like polypeptide 5 & 6.35297 & 0.00005 \\
\hline$M Z B 1$ & 30125 & Marginal zone B- and B1-cell-specific protein & 6.26814 & 0.00005 \\
\hline DERL3 & 14236 & Derlin-3 & 6.2189 & 0.00005 \\
\hline$C D 79 A$ & 1698 & B-Cell antigen receptor complex-associated protein $\alpha$-chain & 6.08902 & 0.0001 \\
\hline FDCSP & 19215 & Follicular dendritic cell secreted peptide & 5.34024 & 0.00005 \\
\hline$S P I B$ & 11242 & Transcription factor Spi-B & 4.89362 & 0.00005 \\
\hline PAX1 & 8615 & Paired box protein Pax-1 & 4.82606 & 0.00005 \\
\hline FCRLA & 18504 & Fc receptor-like A & 4.76497 & 0.00005 \\
\hline STAG3 & 11356 & Cohesin subunit SA-3 & 4.41745 & 0.00055 \\
\hline$L Y Z$ & 6740 & Lysozyme C & 4.3502 & 0.00005 \\
\hline FOSB & 3797 & Protein fosB & 4.32308 & 0.00005 \\
\hline FAM46C & 24712 & Protein FAM46C & 4.27245 & 0.00005 \\
\hline CXCL13 & 10639 & $\mathrm{C}-\mathrm{X}-\mathrm{C}$ motif chemokine 13 & 4.17529 & 0.00005 \\
\hline POU $2 A F 1$ & 9211 & POU domain class 2 -associating factor 1 & 4.06358 & 0.00005 \\
\hline$C D 22$ & 1643 & Siglec-2; CD22 & 3.92959 & 0.00005 \\
\hline IL6 & 6018 & Interleukin-6 & 3.8633 & 0.02522 \\
\hline$A T F 3$ & 785 & Cyclic AMP-dependent transcription factor ATF-3 & 3.42798 & 0.00005 \\
\hline CD180 & 6726 & CD180 Antigen & 3.40267 & 0.0001 \\
\hline CXCR4 & 2561 & C-X-C Chemokine receptor type 4 & 3.31944 & 0.00005 \\
\hline
\end{tabular}

HGNC: Human Gene Nomenclature Committee.

Table VI. The genes most down-regulated in margination of surgical resection compared to normal epithelium.

\begin{tabular}{|c|c|c|c|c|}
\hline Gene symbol & HGNC & Ontology & Fold-change & $p$-Value \\
\hline KRT1 & 6412 & Keratin, type II cytoskeletal 1 & -11.2718 & $5.00 \mathrm{E}-005$ \\
\hline KRT10 & 6413 & Keratin, type I cytoskeletal 10 & -8.14347 & $5.00 \mathrm{E}-005$ \\
\hline$F L G$ & 3748 & Filaggrin & -8.10598 & $5.00 \mathrm{E}-005$ \\
\hline$A S P R V 1$ & 26321 & Retroviral-like aspartic protease 1 & -6.66337 & $5.00 \mathrm{E}-005$ \\
\hline KRTDAP & 16313 & Keratinocyte differentiation-associated protein & -6.06565 & $5.00 \mathrm{E}-005$ \\
\hline MTRNR2L1 & 37155 & Humanin-like 1 & -5.82079 & $5.00 \mathrm{E}-005$ \\
\hline$L C E 3 D$ & 16615 & Late cornified envelope protein 3D & -5.70158 & $5.00 \mathrm{E}-005$ \\
\hline VSIG8 & 27647 & Siglec-8; V-Set and immunoglobulin domain-containing protein 8 & -5.69346 & $5.00 \mathrm{E}-005$ \\
\hline RGS20 & 14600 & Regulator of G-protein signaling 20 & -5.57383 & $5.00 \mathrm{E}-005$ \\
\hline$S P R R 2 B$ & 11262 & Small proline-rich protein $2 \mathrm{~B}$ & -5.53185 & $5.00 \mathrm{E}-005$ \\
\hline$L C E 3 E$ & 29463 & Late cornified envelope protein $3 \mathrm{E}$ & -5.51303 & $5.00 \mathrm{E}-005$ \\
\hline$K R T 3$ & 6440 & Keratin, type II cytoskeletal 3 & -5.2648 & $5.00 \mathrm{E}-005$ \\
\hline KLK9 & 6370 & Kallikrein-9 & -4.96059 & $5.00 \mathrm{E}-005$ \\
\hline LGALS12 & 15788 & Galectin-12 & -4.93873 & $2.46 \mathrm{E}-002$ \\
\hline$S B S N$ & 24950 & Suprabasin & -4.78284 & $5.00 \mathrm{E}-005$ \\
\hline$L G A L S 7 B$ & 34447 & Galectin-7 & -4.49409 & $5.00 \mathrm{E}-005$ \\
\hline$F L G 2$ & 33276 & Filaggrin-2 & -4.44255 & $7.00 \mathrm{E}-004$ \\
\hline TREX2 & 12270 & Three prime repair exonuclease 2 & -4.42317 & $5.00 \mathrm{E}-005$ \\
\hline SERPINB4 & 10570 & Serpin B4 & -4.14905 & $5.00 \mathrm{E}-005$ \\
\hline$K P R P$ & 31823 & Keratinocyte proline-rich protein & -4.08595 & $5.00 \mathrm{E}-005$ \\
\hline
\end{tabular}

HGNC: Human Gene Nomenclature Committee.

of galectin-7-coding mRNA was, in contrast, reduced in most cases (Figure 3). Data sets of comparisons for MSR and SCC are available online: http://www.physiolchem.vetmed.unimuenchen.de/summary/anticancer_research/index.html. The obvious deviations underscore the patient- and sitedependent nature of the characteristics.
Expression of CXCL1, IL6 and IL8 genes was found to be up-regulated in SCC and MSR in comparison to NOE [Figure 4, with MSR having lower levels than SCC (http:// w w w.ph y i o $1 \mathrm{ch}$ e m. ve t m e d. u n i muenchen.de/bilder/zivicova-et-al-suppl-fig-1.jpg)]. Concerning keratins, marked interindividual variability was 
Table VII. The genes imost up-regulated in margin of surgical resection compared to squamous cell carcinoma.

\begin{tabular}{|c|c|c|c|c|}
\hline Gene Symbol & HGNC & Ontology & Fold-change & $p$-Value \\
\hline PRR4 & 18020 & Proline-rich protein 4 & 4.24667 & $1.50 \mathrm{E}-004$ \\
\hline CRISP3 & 16904 & Cysteine-rich secretory protein 3 & 3.72177 & 2.50E-004 \\
\hline$S R P X$ & 11309 & Sushi repeat-containing protein SRPX & 3.42866 & $5.00 \mathrm{E}-005$ \\
\hline$C D 22$ & 1643 & Siglec-2; B-cell receptor CD22 & 3.0965 & $1.50 \mathrm{E}-004$ \\
\hline CXCL12 & 10672 & Stromal cell-derived factor 1 & 2.78279 & $5.00 \mathrm{E}-005$ \\
\hline$M M R N 1$ & 7178 & Multimerin-1 & 2.76234 & $5.00 \mathrm{E}-005$ \\
\hline GFRA1 & 4243 & GDNF family receptor $\alpha 1$ & 2.73579 & $5.00 \mathrm{E}-005$ \\
\hline$A B C A 8$ & 38 & ATP-Binding cassette sub-family A member 8 & 2.71081 & $2.50 \mathrm{E}-004$ \\
\hline$A B I 3 B P$ & 17265 & Target of Nesh-SH3 & 2.63971 & 4.00E-004 \\
\hline$A D R A 2 A$ & 281 & $\alpha 2 \mathrm{~A}$ adrenergic receptor & 2.60041 & $3.00 \mathrm{E}-004$ \\
\hline$A N K 2$ & 493 & Ankyrin-2 & 2.59542 & $2.50 \mathrm{E}-004$ \\
\hline$R E C K$ & 11345 & Reversion-inducing cysteine-rich protein with Kazal motifs & 2.5949 & $5.00 \mathrm{E}-005$ \\
\hline$B L K$ & 1057 & Tyrosine-protein kinase Blk & 2.56796 & $5.00 \mathrm{E}-004$ \\
\hline HSPB6 & 26511 & Heat shock protein $\beta 6$ & 2.51233 & $2.50 \mathrm{E}-004$ \\
\hline VPREB3 & 12710 & Pre-B lymphocyte protein 3 & 2.48558 & $1.00 \mathrm{E}-004$ \\
\hline$C C L 21$ & 10620 & C-C motif chemokine 21 & 2.41223 & $3.00 \mathrm{E}-004$ \\
\hline COL14A1 & 2191 & Collagen $\alpha 1$ (XIV)-chain & 2.20506 & $5.00 \mathrm{E}-005$ \\
\hline PDK4 & 8812 & $\begin{array}{l}\text { [Pyruvate dehydrogenase (acetyl-transferring)] } \\
\text { kinase isozyme } 4 \text {, mitochondrial }\end{array}$ & 2.17112 & $4.00 \mathrm{E}-004$ \\
\hline PTGDS & 9592 & Prostaglandin-H2 D-isomerase & 2.15497 & $5.00 \mathrm{E}-005$ \\
\hline$V W A 8$ & 29071 & von Willebrand factor A domain-containing protein 8 & 2.13467 & $5.00 \mathrm{E}-005$ \\
\hline
\end{tabular}

HGNC: Human Gene Nomenclature Committee.

Table VIII. The genes most down-regulated in margin of surgical resection compared to squamous cell carcinoma.

\begin{tabular}{|c|c|c|c|c|}
\hline Gene symbol & HGNC & Ontology & Fold-change & $p$-Value \\
\hline$C L C$ & 2014 & Galectin-10 & -5.7305 & $1.81 \mathrm{E}-002$ \\
\hline KRT17 & 6427 & Keratin, type I cytoskeletal 17 & -4.76107 & $5.00 \mathrm{E}-005$ \\
\hline KRT14 & 6416 & Keratin, type I cytoskeletal 14 & -4.50188 & $2.90 \mathrm{E}-003$ \\
\hline CNTNAP2 & 13830 & Contactin-associated protein-like 2 & -3.85258 & $5.00 \mathrm{E}-005$ \\
\hline$K L K 9$ & 6370 & Kallikrein-9 & -3.78367 & $5.00 \mathrm{E}-005$ \\
\hline EPPK1 & 15577 & Epiplakin & -3.36048 & $5.00 \mathrm{E}-005$ \\
\hline$L A M C 2$ & 6493 & Laminin subunit $\gamma 2$ & -3.34597 & $5.00 \mathrm{E}-005$ \\
\hline TUBB3 & 20772 & Tubulin $\beta 3$ chain & -3.3348 & $5.00 \mathrm{E}-005$ \\
\hline$R B P 1$ & 16831 & Peripheral-type benzodiazepine receptor-associated protein 1 & -3.3028 & $5.00 \mathrm{E}-005$ \\
\hline PTHLH & 9607 & Parathyroid hormone-related protein & -3.17485 & $1.00 \mathrm{E}-004$ \\
\hline CSPG4 & 2466 & Chondroitin sulfate proteoglycan 4 & -3.16629 & $1.00 \mathrm{E}-004$ \\
\hline$H A P 1$ & 4812 & Huntingtin-associated protein 1 & -3.15833 & $5.00 \mathrm{E}-005$ \\
\hline$K L H D C 7 B$ & 25145 & Kelch domain-containing protein $7 \mathrm{~B}$ & -3.1501 & $5.00 \mathrm{E}-005$ \\
\hline$I L 12 R B 2$ & 5972 & Interleukin-12 receptor subunit $\beta 2$ & -3.13533 & $5.00 \mathrm{E}-005$ \\
\hline IFI6 & 4054 & Interferon $\alpha$-inducible protein 6 & -3.06252 & $5.00 \mathrm{E}-005$ \\
\hline$M M P 12$ & 7158 & Macrophage metalloelastase & -2.94276 & $5.00 \mathrm{E}-005$ \\
\hline S100A7 & 10497 & Protein S100-A7 & -2.92962 & $1.00 \mathrm{E}-004$ \\
\hline WDR66 & 28506 & WD Repeat-containing protein 66 & -2.87516 & $5.00 \mathrm{E}-005$ \\
\hline$A D A M 23$ & 202 & Disintegrin and metalloproteinase domain-containing protein 23 & -2.71994 & $2.50 \mathrm{E}-004$ \\
\hline
\end{tabular}

HGNC: Human Gene Nomenclature Committee.

noted for keratin 5 and 6 , their expression levels generally being lower in MSR than in NOE samples (Figure 4). Expression of keratins 8, 14, 17 and 19 was up-regulated in SCC relative to NOE, 8 and 19 were also up-regulated in MSR in comparison to NOE (Figure 4). Keratin 14 and
17 genes were expressed to a lower extent in MSR than in NOE, with exceptions (Figure 4). Transcript levels for all studied keratins except for keratin 19 were lower in MSR than in SCC (http://www.physiolchem.vetmed.unimuenchen.de/bilder/zivicova-et-al-suppl-fig-1.jpg). 


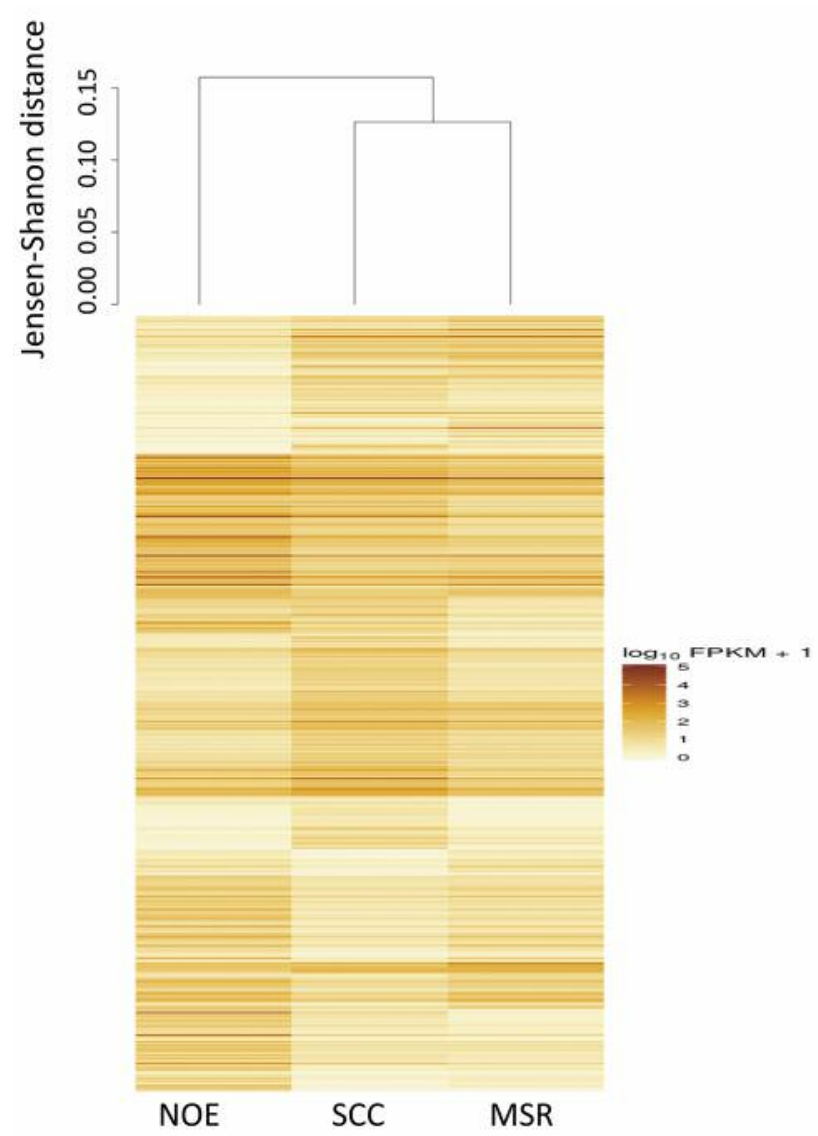

Figure 1. Heat map showing genes differentially expressed between squamous cell carcinoma (SCC), normal epithelium (NOE) and margin of surgical resection (MSR) at a statistically significant level. Mutual relations between the three types of tested specimen are presented in the dendrogram (based on Jensen-Shannon distances) at 5\% false discovery rates $(F D R)$ and fragments per kilobase of exon per million fragments mapped (FPKM).

Immunohistochemical analysis. A common feature of all cases for immunopositivity was their interindividual variability. Table $\mathrm{X}$ gives a detailed account of this parameter for each patient, Figure 5 presents exemplary illustrations for each galectin. Galectin-1 was neither detected in SCC/NOE nor in the epithelium of the MSR, but was found in the extracellular matrix of cancer stroma (Figure 5, top panel). Galectin-3 was present in tumor stroma, namely in inflammatory leukocytes, and in malignant epithelium, in MSR samples in the epithelium, whereas staining of NOE was negative or revealing a very weak signal in the epithelium (Figure 5). No positivity for galectin-4 was observed in normal or SCC samples, a limited number of cells expressing galectin-7 were found in two cases (Figure 5). Five samples of NOE exhibited immunopositivity for galectin-7 and two samples were negative (Figure 5). Whereas galectin-8 was not detected, signals for
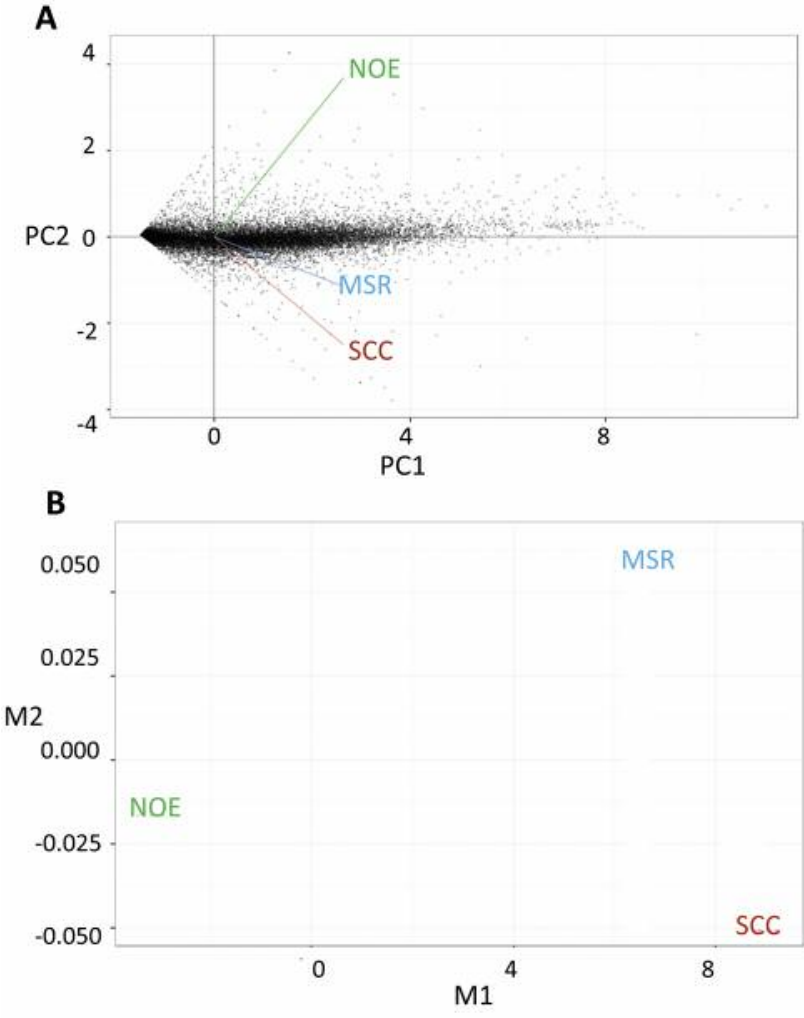

Figure 2. Principial component analysis (PCA) for dimensionality reduction showing a strong relation between gene expression in squamous cell carcinoma (SCC) and margin of surgical resection (MSR) in comparison with normal epithelium (NOE) (A). A similar scenario is obtained by multi-dimensional scaling for dimensionality reduction $(B)$.

galectin-9 were seen in the basal layer of two samples of NOE. In SCC and MSR samples, it was detected in infiltrating leukocytes, ascertained by signal overlap with positivity for CD45 (Figure 5, bottom panel).

Keratins 8, 14, 17 and 19, at a level of interindividual variability similar to galectins, were positively stained in SCC cases (Table XI, Figure 5). No signal for keratin 8 was detected in NOE, keratins 14,17 and 19 were observed in the majority of tumors, expression of 14 and 19 was present in the basal layer of normal epithelium and also in MSR.

\section{Discussion}

Genome-wide expression profiling was applied on specimens from seven patients, for each patient from three sites. Obviously, when using normal tissue (unaffected, from the other cheek) as a reference, it was possible to compare material from the tumor and the margin. Thus, a full-scale set of pairwise comparisons between normal, margin and tumor specimens is presented. Beyond pinpointing disparities, we 


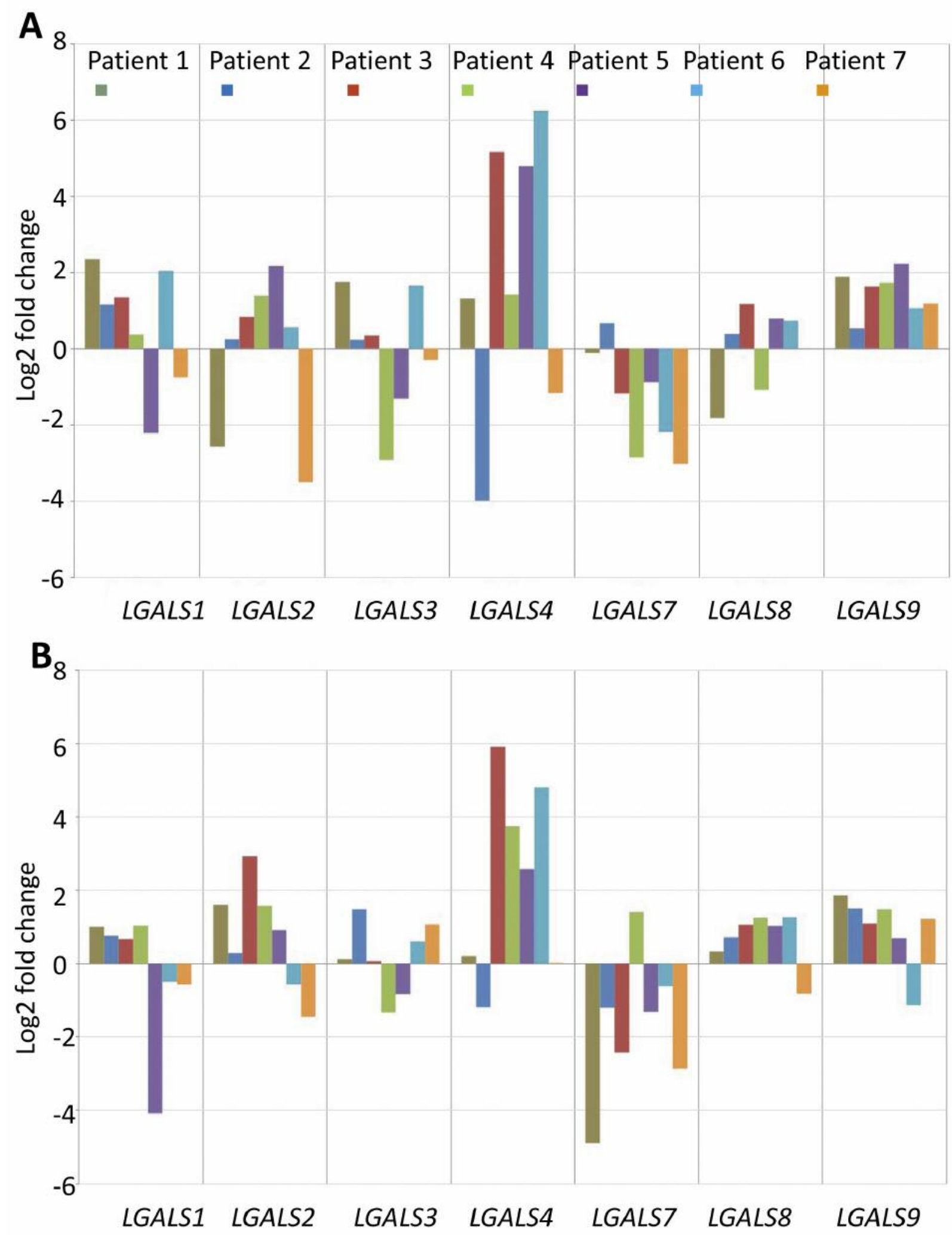

Figure 3. Log2 fold-change as a measure of up- or down-regulation of gene expression for galectins (LGAL). Down-regulated genes have negative $\log 2$ value, positive log2 values identify gene up-regulation. Comparisons between squamous cell carcinoma (SCC) and normal epithelium (NOE) $(A)$, and margin of surgical resection (MSR) and normal epithelium (NOE) (B) are given. 

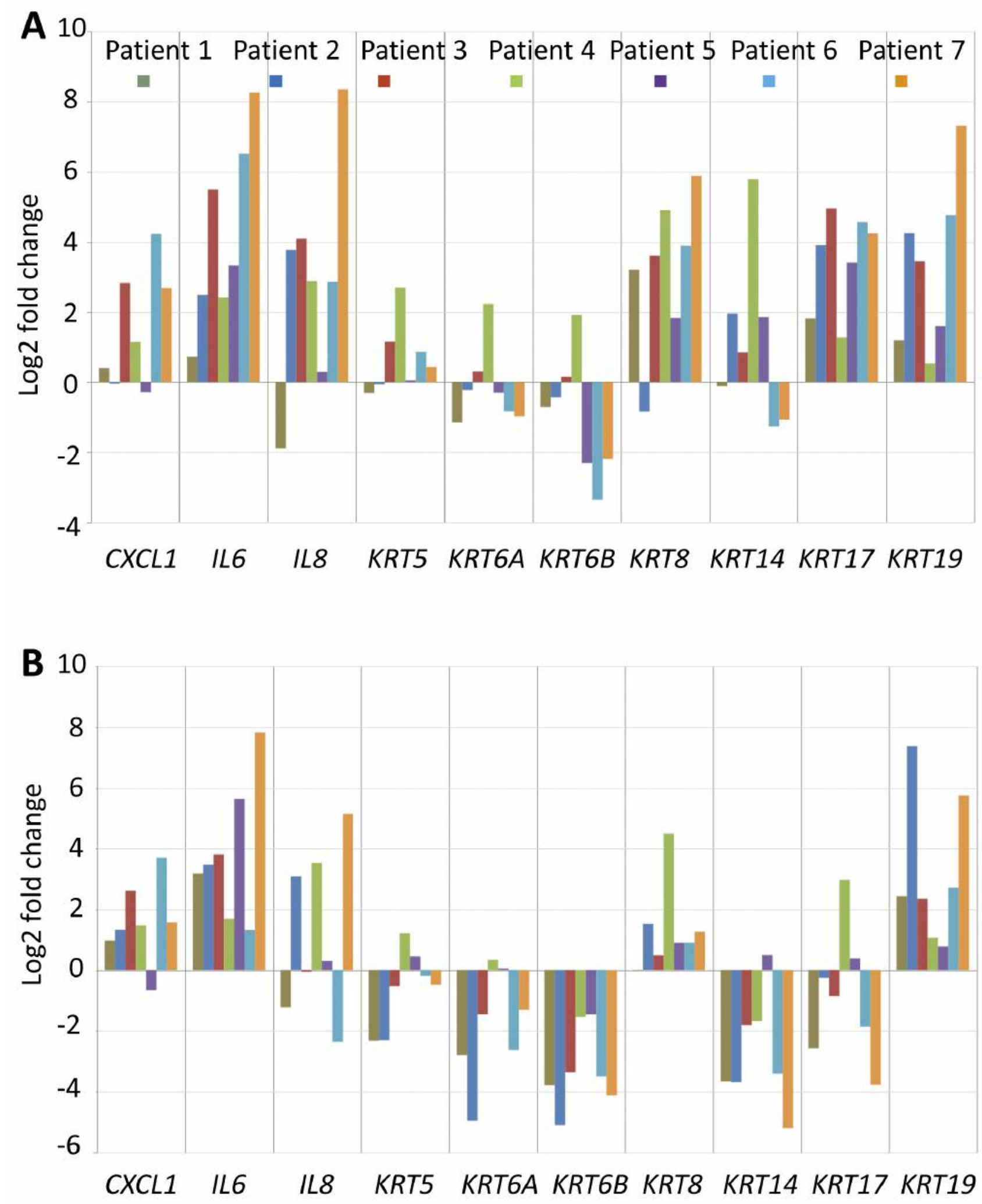

Figure 4. Log2 fold-change for expression of genes for interleukins (IL6, IL8), for chemokine (C-X-C motif) ligand 1 (CXCL1) (A) and for keratins $(K R T)(B)$. Down-regulated genes have negative $\log 2$ value, positive log2 values identify gene up-regulation. Comparisons between squamous cell carcinoma (SCC) and normal epithelium (NOE) (A), and margin of surgical resection (MSR) and normal epithelium (NOE) (B) are given. 

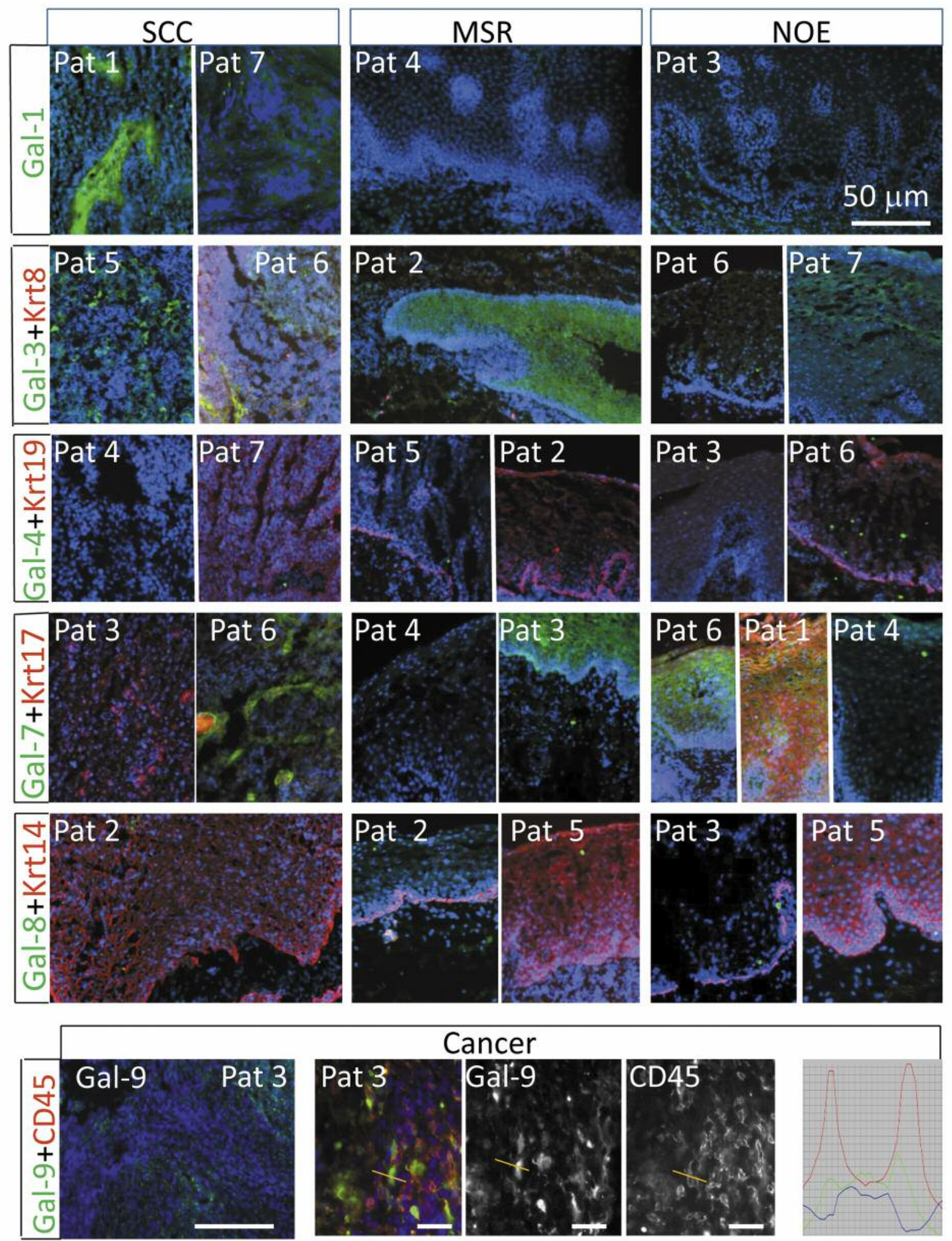

Figure 5. Immunodetection of galectins (G, green signal): Gal-1, Gal-3, Gal-4, Gal-7, Gal-8 and Gal-9. Keratins (KRT) such as 8, 19, 17 and 14 and the leukocyte marker CD45 (red signal) were also detected in representative samples of squamous cell cancer (SCC), margin of surgical resection $(M S R)$ and normal oral epithelium (NOE). The number of the patient is given in each panel. The fluorescence profiles of galectin-9 and CD45 provide information on co-localization (the measured cell is marked by a yellow line). Nuclei were counterstained by 4',6-diamidine-2-phenylindole. 
Table IX. Gene Ontology (GO) biological process classification for the genes most up-regulated between squamous cell carcinoma and normal epithelium ( $\log 2$ fold-change $>2, p<0.05$ ).

\begin{tabular}{lccccc}
\hline Term & Overlap & $p$-Value & $p$-Value & Z-Score & Combined score \\
\hline Extracellular region (GO:0005576) & $11 / 1585$ & 0.0040136377 & 0.2107604977 & -2.6323608589 & 4.0986723883 \\
Collagen trimer (GO:0005581) & $3 / 91$ & 0.0021218384 & 0.2107604977 & -2.1962328608 & 3.4196067589 \\
Endoplasmic reticulum lumen (GO:0005788) & $3 / 154$ & 0.0092105819 & 0.2107604977 & -2.1804963949 & 3.3951045642 \\
Extracellular matrix (GO:0031012) & $4 / 348$ & 0.0162722728 & 0.2107604977 & -2.1565801777 & 3.3578662278 \\
Extracellular space (GO:0005615) & $8 / 1120$ & 0.0122587112 & 0.2107604977 & -2.1529752424 & 3.352253225 \\
Heterochromatin (GO:0000792) & $2 / 68$ & 0.0155862027 & 0.2107604977 & -2.1291495068 & 3.3151557715 \\
Potassium channel complex (GO:0034705) & $2 / 71$ & 0.0169120267 & 0.2107604977 & -1.9838354847 & 3.0888970623 \\
Voltage-gated potassium channel complex (GO:0008076) & $2 / 70$ & 0.0164648846 & 0.2107604977 & -1.9741441399 & 3.0738073199 \\
Chromatin (GO:0000785) & $3 / 289$ & 0.047243783 & 0.2189756086 & -1.9563400033 & 2.9712792812 \\
Late endosome (GO:0005770) & $2 / 107$ & 0.0362100659 & 0.2115430167 & -1.8277730107 & 2.8391290074 \\
Nuclear chromosome part (GO:0044454) & $3 / 327$ & 0.0636854817 & 0.2215358089 & -1.8234538826 & 2.7482568793 \\
Extracellular matrix part (GO:0044420) & $2 / 127$ & 0.0493188308 & 0.2189756086 & -1.6694709902 & 2.5355840781 \\
Early endosome (GO:0005769) & $2 / 141$ & 0.0593625463 & 0.2215358089 & -1.645528775 & 2.4800933105 \\
Cation channel complex (GO:0034703) & $2 / 147$ & 0.0638661791 & 0.2215358089 & -1.5737064331 & 2.3718447569 \\
\hline
\end{tabular}

Combined score $>2$ according to (57) is shown.

Table X. Immunopositivity for galectins.

\begin{tabular}{|c|c|c|c|c|c|c|c|c|}
\hline Patient no. & Tumor site & Type of tissue & Gal-1 $1^{x}$ & Gal-3* & Gal-4 & Gal-7 & Gal-8 & Gal-9* \\
\hline \multirow[t]{3}{*}{1} & \multirow[t]{3}{*}{ Tonsills } & NOE & - & - & - & + & - & + \\
\hline & & MSR & - & - & - & + & - & - \\
\hline & & SCC & + & + & - & $-1+$ & - & - \\
\hline \multirow[t]{3}{*}{2} & \multirow[t]{3}{*}{ Oropharynx } & NOE & - & - & - & + & - & - \\
\hline & & MSR & - & + & - & + & - & - \\
\hline & & SCC & + & - & - & - & - & - \\
\hline \multirow[t]{3}{*}{3} & \multirow[t]{3}{*}{ Tonsills } & NOE & - & - & - & + & - & - \\
\hline & & MSR & - & - & - & - & - & - \\
\hline & & SCC & + & - & - & - & - & - \\
\hline \multirow[t]{3}{*}{4} & \multirow[t]{3}{*}{ Tonsills } & NOE & - & - & - & - & - & - \\
\hline & & MSR & - & - & - & - & - & - \\
\hline & & SCC & - & - & - & - & - & - \\
\hline \multirow[t]{3}{*}{5} & \multirow[t]{3}{*}{ Tonsills } & NOE & - & - & - & + & - & + \\
\hline & & MSR & - & - & - & + & - & - \\
\hline & & SCC & - & + & - & - & - & - \\
\hline \multirow[t]{3}{*}{6} & \multirow[t]{3}{*}{ Tonsills } & NOE & - & + & - & + & - & - \\
\hline & & MSR & - & - & - & + & - & - \\
\hline & & SCC & + & + & - & $-1+$ & - & - \\
\hline \multirow[t]{3}{*}{7} & \multirow[t]{3}{*}{ Tonsiils } & NOE & - & + & - & - & - & - \\
\hline & & MSR & - & + & - & + & - & - \\
\hline & & SCC & - & - & - & - & - & - \\
\hline
\end{tabular}

NOE: Normal epithelium, MSR: margin of surgical resection, SCC: squamous cell carcinoma. xExtracellular matrix, *positive leukocytes, -/+ positivity confined to few cells.

focused on a class of emerging bioeffectors to investigate their significance of this factor, i.e. site of specimen, at the level of the individual patient. Of note, special attention is given to the question of whether, in this group, the interindividual variability could even reach divergent patterns of up- and down-regulation instead of quantitative differences.
Galectins form a family of tissue lectins, which share reactivity to $\beta$-galactosides and the capacity to trigger postbinding effects. Intriguingly, these can be additive or antagonistic, as the examples of galectins- 1 and -3 in osteoarthritis progression or in anoikis induction in pancreatic carcinoma cells attest (46-49). Moreover, an inducer of differentiation (butyrate) revealed differences in responsiveness 
between family members (50), and galectins can alter the proteomic profile of tumor cells, demonstrating an impact of galectin presence on expression (51). As consequence, it appears to make sense to proceed from recording the expression profile of a single or few proteins to a network analysis. On the histopathological side, this study was deliberately designed to include normal tissue from each patient. In addition to a comparison between tumor and normal tissue from the same patient, we also included a specimen of the surgical margin in order to address the issue as to whether and to what extent expression characteristics in this region deviate from that of tumor/normal tissue. Given the possibility that the studied gene products may have potential for therapeutic innovation, the application of the same protocol to specimens from several patients enables estimation of the extent of interindividual variations. In this sense, we obtained a fingerprint for galectin expression from three different sites for clinical specimens.

Our data revealed differential regulation among the galectin family with up- and down-regulation and interindividual variability. The resection margin can still show features of the SCC region that may signal the presence of tumor cells. The MSR zone appeared macro- and microscopically normal, whereas its gene-expression profile presented similarities to the cancer specimen. Because individual patients in this group presented exceptional behavior, a verification of expression at the protein (effector) level seems to be necessary before any decision on tumor management may be considered. Thus, salient lessons arising from the present results on galectins are that gene regulation is different for different galectin family numbers in SCC and among patients. Having tested antibody preparations applied in previous studies on head and neck SCCs (22-26), the possibility for false-negativity in staining is excluded, as confirmed by flanking immunohistochemical keratin localization. Given the possibility for applying human galectins as tools in tumor pathology $(52,53)$, such work can extend the given scope of analysis.

As a consequence of the reported expression of several galectins, it is advised that histopathological studies on galectins be carried out as a network analysis, as illustrated by this report and previously by respective mapping during development in a phylogenetic model (53-56). The possibility of functional antagonism and cooperation among galectin family members should be followed-up by experimental studies. Clinically, the noted interindividual variability calls for thorough analysis of each case prior to reaching clinically relevant conclusions.

\section{Acknowledgements}

The Authors are grateful for funding by the Ministry of Health of the Czech Republic, project No. 15-28933A, the Charles University, projects PROGRES Q28/1LF, UNCE 204013 and Specific University Research, as well as by the Ministry of Education, Youth and Sports of the Czech Republic within the National Sustainability Program II
Table XI. Immunopositivity for selected keratins.

\begin{tabular}{lcccccc}
\hline $\begin{array}{l}\text { Patient } \\
\text { no. }\end{array}$ & $\begin{array}{c}\text { Tumor } \\
\text { site }\end{array}$ & $\begin{array}{c}\text { Type of } \\
\text { tissue }\end{array}$ & KRT8 & KRT14 & KRT17 & KRT19 \\
\hline 1 & \multirow{2}{*}{ Tonsills } & NOE & - & $+*$ & + & + \\
& & MSR & + & $+*$ & - & $+*$ \\
& & SCC & + & + & - & + \\
2 & Oropharynx & NOE & - & $+*$ & - & - \\
& & MSR & - & + & - & - \\
& & SCC & - & + & + & + \\
3 & Tonsills & NOE & - & + & - & - \\
& & MSR & + & + & - & - \\
& & SCC & + & + & + & + \\
4 & Tonsills & NOE & - & + & - & - \\
& & MSR & - & + & - & - \\
& & SCC & + & + & - & - \\
5 & Tonsills & NOE & - & $+*$ & - & + \\
& & MSR & + & $+*$ & - & + \\
& & SCC & + & - & + & + \\
6 & Tonsills & NOE & - & + & - & + \\
& & MSR & + & + & - & - \\
& & SCC & + & + & - & + \\
7 & Tonsills & NOE & - & + & - & - \\
& & MSR & + & + & - & - \\
& & SCC & + & $-/+$ & - & + \\
\hline
\end{tabular}

NOE: Normal epithelium, MSR: margin of surgical resection, SCC: squamous cell carcinoma. *Positivity in suprabasal leukocytes.

(project BIOCEV-FAR reg. no. LQ1604) and project BIOCEV (CZ.1.05/1.1.00/02.0109). This publication is a result of the project implementation, covering expenses for equipment for bioanalyses (No CZ.1.05/2.1.00/19.0400), supported by the Research and Development for Innovations Operational Program (RDIOP) co-financed by European Regional Development Fund and the state budget of the Czech Republic. The Authors thank to Radana Kavková, M.Sc. and Marie Jindráková for excellent technical assistance.

\section{References}

1 Marur S and Forastiere AA: Head and neck squamous cell carcinoma: update on epidemiology, diagnosis, and treatment. Mayo Clin Proc 91: 386-396, 2016.

2 Gumusay O, Ozet A, Buyukberber S, Baykara M, Coskun U, Cetin B, Uner A, Aydil U and Benekli M: Factors predicting the development of distant metastases in patients with head and neck squamous cell carcinoma: a retrospective study from a single centre. J BUON 20: 521-526, 2015.

3 Barber BR, Biron VL, Klimowicz AC, Puttagunta L, Côté DW and Seikaly $\mathrm{H}$ : Molecular predictors of locoregional and distant metastases in oropharyngeal squamous cell carcinoma. J Otolaryngol Head Neck Surg 16: 42-53, 2013.

4 Taghavi N and Yazdi I: Prognostic factors of survival rate in oral squamous cell carcinoma: clinical, histologic, genetic and molecular concepts. Arch Iran Med 18: 314-319, 2015.

5 Corfield A: Eukaryotic protein glycosylation: a primer for histochemists and cell biologists. Histochem Cell Biol 147: 119147, 2017. 
6 Kopitz J: Lipid glycosylation: a primer for histochemists and cell biologists. Histochem Cell Biol 147: 175-198, 2017.

7 Solís D, Bovin NV, Davis AP, Jiménez-Barbero J, Romero A, Roy R, Smetana K Jr. and Gabius H-J: A guide into glycosciences: how chemistry, biochemistry and biology cooperate to crack the sugar code. Biochim Biophys Acta 1850: 186-235, 2015.

8 Gabius H-J: The magic of the sugar code. Trends Biochem Sci 40: 341, 2015.

9 Gabius H-J, Kaltner H, Kopitz J and André S: The glycobiology of the $\mathrm{CD}$ system: a dictionary for translating marker designations into glycan/lectin structure and function. Trends Biochem Sci 40: 360-376, 2015.

10 Gabius H-J and Roth J: An introduction to the sugar code. Histochem Cell Biol 147: 111-117, 2017.

11 Gabius H-J, Manning JC, Kopitz J, André S and Kaltner H: Sweet complementarity: the functional pairing of glycans with lectins. Cell Mol Life Sci 73: 1989-2016, 2016.

12 Manning JC, Romero A, Habermann F, García Caballero G, Kaltner H and Gabius H-J: Lectins: a primer for histochemists and cell biologists. Histochem Cell Biol 147: 199-222, 2017.

13 Roth J and Zuber C: Quality control of glycoprotein folding and ERAD: the role of N-glycan handling, EDEM1 and OS-9. Histochem Cell Biol 147: 269-284, 2017.

14 Amano M, Eriksson H, Manning JC, Detjen KM, André S, Nishimura S-I, Lehtiö J and Gabius H-J: Tumour suppressor p16 ${ }^{I N K 4 a}$ : anoikis-favouring decrease in $\mathrm{N} / \mathrm{O}$-glycan/cell surface sialylation by down-regulation of enzymes in sialic acid biosynthesis in tandem in a pancreatic carcinoma model. FEBS J 279: 4062-4080, 2012.

15 Bhide GP and Colley KJ: Sialylation of $N$-glycans: mechanism, cellular compartmentalization and function. Histochem Cell Biol 147: 149-174, 2017.

16 Gabius HJ, Engelhardt R and Cramer F: Endogenous tumor lectins: overview and perspectives. Anticancer Res 6: 573-578, 1986.

17 Kaltner $\mathrm{H}$ and Gabius H-J: A toolbox of lectins for translating the sugar code: the galectin network in phylogenesis and tumors. Histol Histopathol 27: 397-416, 2012.

18 Kaltner H, Toegel S, García Caballero G, Manning JC, Ledeen RW and Gabius H-J: Galectins: their network and roles in immunity/tumor growth control. Histochem Cell Biol 147: 239256, 2017.

19 Gillenwater A, Xu XC, El-Naggar AK, Clayman GL and Lotan $\mathrm{R}$ : Expression of galectins in head and neck squamous cell carcinoma. Head \& Neck 18: 422-432, 1996.

20 Gillenwater A, Xu X-C, Estrov Y, Sacks PG, Lotan D and Lotan $\mathrm{R}$ : Modulation of galectin-1 content in human head and neck squamous carcinoma cells by sodium butyrate. Int $\mathrm{J}$ Cancer 75 : 217-224, 1998.

21 Piantelli M, Iacobelli S, Almadori G, Iezzi M, Tinari N, Natoli C, Cadoni G, Lauriola L and Ranelletti FO: Lack of expression of galectin-3 is associated with a poor outcome in node-negative patients with laryngeal squamous cell carcinoma. J Clin Oncol 20: 3850-3856, 2002 .

22 Saussez S, Decaestecker C, Lorfevre F, Cucu D-R, Mortuaire G, Chevalier D, Wacreniez A, Kaltner H, André S, Toubeau G, Camby I, Gabius H-J and Kiss R: High level of galectin-1 expression is a negative prognostic predictor of recurrence in laryngeal squamous cell carcinomas. Int J Oncol 30: 1109-1117, 2007.
23 Saussez S, Decaestecker C, Mahillon V, Cludts S, Capouillez A, Chevalier D, Vet HK, André S, Toubeau G, Leroy X and Gabius H-J: Galectin-3 up-regulation during tumor progression in head and neck cancer. Laryngoscope 118: 1583-1590, 2008.

24 Saussez S, Decaestecker C, Cludts S, Ernoux P, Chevalier D, Smetana K Jr, André S, Leroy X and Gabius H-J: Adhesion/ growth-regulatory tissue lectin galectin-1 in relation to angiogenesis/lymphocyte infiltration and prognostic relevance of stromal up-regulation in laryngeal carcinomas. Anticancer Res 29: 59-65, 2009.

25 Saussez S, Cucu D-R, Decaestecker C, Chevalier D, Kaltner H, André S, Wacreniez A, Toubeau G, Camby I, Gabius H-J and Kiss R: Galectin-7 (p53-induced gene-1): a new prognostic predictor of recurrence and survival in stage IV hypopharyngeal cancer. Ann Surg Oncol 13: 999-1009, 2006.

26 Cludts S, Decaestecker C, Mahillon V, Chevalier D, Kaltner H, André S, Remmelink M, Leroy X, Gabius H-J and Saussez S: Galectin-8 up-regulation during hypopharyngeal and laryngeal tumor progression and comparison with galectin-1, -3 and -7. Anticancer Res 29: 4933-4940, 2009.

27 Dong GW, Kim J, Park JH, Choi JY, Cho SI and Lim SC: Galectin-8 expression in laryngeal squamous cell carcinoma. Clin Exp Otorhinolaryngol 2: 13-19, 2009.

28 Alves PM, Godoy GP, Gomes DQ, Medeiros AM, de Souza LB, da Silveira EJ, Vasconcelos MG and Queiroz LM: Significance of galectin-1, -3, -4 and -7 in the progression of squamous cell carcinoma of the tongue. Pathol Res Pract 207: 236-240, 2011.

29 Fík Z, Valach J, Chovanec M, Mazánek J, Kodet R, Kodet O, Tachezy R, Foltynova E, André S, Kaltner H, Gabius H-J and Smetana K Jr: Loss of adhesion/growth-regulatory galectin-9 from squamous cell epithelium in head and neck carcinomas. J Oral Pathol Med 42: 166-173, 2013.

30 Matsukawa S, Morita K, Negishi A, Harada H, Nakajima Y, Shimamoto H, Tomioka H, Tanaka K, Ono M, Yamada T and Omura K: Galectin-7 as a potential predictive marker of chemoand/or radio-therapy resistance in oral squamous cell carcinoma. Cancer Med 3: 349-361, 2014.

31 Muniz JM, Bibiano Borges CR, Beghini M, de Araujo MS, Miranda Alves P, de Lima LM, Pereira SA, Nogueira RD, Napimoga MH, Rodrigues V Jr and Rodrigues DB: Galectin-9 as an important marker in the differential diagnosis between oral squamous cell carcinoma, oral leukoplakia and oral lichen planus. Immunobiology 220: 1006-1011, 2015.

$32 \mathrm{Wu}$ MH, Hong TM, Cheng HW, Pan SH, Liang YR, Hong HC, Chiang WF, Wong TY, Shieh DB, Shiau AL, Jin YT and Chen YL: Galectin-1-mediated tumor invasion and metastasis, upregulated matrix metalloproteinase expression, and reorganized actin cytoskeletons. Mol Cancer Res 7: 311-318, 2009.

33 Valach J, Fík Z, Strnad H, Chovanec M, Plzák J, Cada Z, Szabo P, Sáchova J, Hroudová M, Urbanová M, Steffl M, Pačes J, Mazanek J, Vlček C, Betka J, Kaltner H, André S, Gabius H-J, Kodet R, Smetana K Jr, Gál P and Kolár M: Smooth muscle actin-expressing stromal fibroblasts in head and neck squamous cell carcinoma: increased expression of galectin-1 and induction of poor prognosis factors. Int J Cancer 131: 2499-2508, 2012.

34 Rizqiawan A, Tobiume K, Okui G, Yamamoto K, Shigeishi H, Ono S, Shimasue H, Takechi M, Higashikawa K and Kamata N: Autocrine galectin-1 promotes collective cell migration of squamous cell carcinoma cells through up-regulation of distinct integrins. Biochem Biophys Res Commun 441: 904-910, 2013. 
35 Moll R, Divo M and Langbein L: The human keratins: biology and pathology. Histochem Cell Biol 129: 705-733, 2008.

36 Kurokawa I, Takahashi K, Moll I and Moll R: Expression of keratins in cutaneous epithelial tumors and related disorders: distribution and clinical significance. Exp Dermatol 20: 217-228, 2011.

37 Ewels P, Magnusson M, Lundin S and Käller M: MultiQC: Summarize analysis results for multiple tools and samples in a single report. Bioinformatics 32: 3047-3048, 2016.

38 Trapnell C, Pachter L and Salzberg S: TopHat: discovering splice junctions with RNA-Seq. Bioinformatics 25: 1105-1111, 2009.

39 Trapnell C, Roberts A, Goff L, Pertea G, Kim D, Kelley DR, Pimentel H, Salzberg SL, Rinn JL and Pachter L: Differential gene and transcript expression analysis of RNA-seq experiments with TopHat and Cufflinks. Nat Protoc 7: 562-578, 2012.

40 Goff L, Trapnell C and Kelley D: cummeRbund: analysis, exploration, manipulation, and visualization of Cufflinks highthroughput sequencing data. R package version 2.14.0. 2013.

41 Mi H, Huang X, Muruganujan A, Tang H, Mills C, Kang D and Thomas PD: PANTHER version 11: expanded annotation data from Gene Ontology and Reactome pathways, and data analysis tool enhancements. Nucleic Acids Res 45: D183-D189, 2017.

42 Kaltner H, Seyrek K, Heck A, Sinowatz F and Gabius H-J: Galectin-1 and galectin-3 in fetal development of bovine respiratory and digestive tracts. Comparison of cell type-specific expression profiles and subcellular localization. Cell Tissue Res 307: 35-46, 2002.

43 Purkrábková T, Smetana K Jr, Dvoránková B, Holíková Z, Böck C, Lensch M, André S, Pytlík R, Liu F-T, Klíma J, Smetana K, Motlík J and Gabius H-J: New aspects of galectin functionality in nuclei of cultured bone marrow stromal and epidermal cells: biotinylated galectins as tool to detect specific binding sites. Biol Cell 95: 535-545, 2003.

44 Čada Z, Smetana K Jr., Lacina L, Plzáková Z, Stork J, Kaltner H, Russwurm R, Lensch M, André S and Gabius H-J: Immunohistochemical fingerprinting of the network of seven adhesiongrowthregulatory lectins in human skin and detection of distinct tumourassociated alterations. Folia Biol 55: 145-152, 2009.

45 Čada Z, Chovanec M, Smetana K Jr, Betka J, Lacina L, Plzák J, Kodet R, Stork J, Lensch M, Kaltner H, André S and Gabius H$\mathrm{J}$ : Galectin-7: Will the lectin's activity establish clinical correlations in head and neck squamous cell and basal cell carcinomas? Histol Histopathol 21: 41-48, 2009.

46 Sanchez-Ruderisch H, Fischer C, Detjen KM, Welzel M, Wimmel A, Manning JC, André S and Gabius H-J: Tumor suppressor p16INK4a: down-regulation of galectin-3, an endogenous competitor of the pro-anoikis effector galectin-1, in a pancreatic carcinoma model. FEBS J 277: 3552-3563, 2010.

47 Toegel S, Weinmann D, André S, Walzer SM, Bilban M, Schmidt S, Chiari C, Windhager R, Krall C, Bennani-Baiti IM and Gabius H-J: Galectin-1 couples glycobiology to inflammation in osteoarthritis through the activation of an NF-kB-regulated gene network. J Immunol 196: 1910-1921, 2016.
48 Toegel S, Bieder D, André S, Kayser K, Walzer SM, Hobusch G, Windhager R and Gabius H-J: Human osteoarthritic knee cartilage: fingerprinting of adhesion/growth-regulatory galectins in vitro and in situ indicates differential upregulation in severe degeneration. Histochem Cell Biol 142: 373-388, 2014.

49 Weinmann D, Schlangen K, André S, Schmidt S, Walzer SM, Kubista B, Windhager R, Toegel S and Gabius H-J: Galectin-3 induces a pro-degradative/inflammatory gene signature in human chondrocytes, teaming up with galectin-1 in osteoarthritis pathogenesis. Sci Rep 6: 39112, 2016.

50 Katzenmaier E-M, André S, Kopitz J and Gabius H-J: Impact of sodium butyrate on the network of adhesion/growth-regulatory galectins in human colon cancer in vitro. Anticancer Res 34 : 5429-5438, 2014.

51 Michalak M, Warnken U, André S, Schnölzer M, Gabius H-J and Kopitz J: Detection of proteome changes in human colon cancer induced by cell surface binding of growth-inhibitory human galectin-4 using quantitative SILAC-based proteomics. J Proteome Res 15: 4412-4422, 2016.

52 Plzák J, Betka J, Smetana K Jr, Chovanec M, Kaltner H, André S, Kodet R and Gabius H-J: Galectin-3: an emerging prognostic indicator in advanced head and neck carcinoma. Eur J Cancer 40: 2324-2330, 2004.

53 Dawson H, André S, Karamitopoulou E, Zlobec I and Gabius H$\mathrm{J}$ : The growing galectin network in colon cancer and clinical relevance of cytoplasmic galectin-3 reactivity. Anticancer Res 33: 3053-3059, 2013.

54 Kaltner H, Singh T, Manning JC, Raschta A-S, André S, Sinowatz F and Gabius H-J: Network monitoring of adhesion/ growth-regulatory galectins: localization of the five canonical chicken proteins in embryonic and maturing bone and cartilage and their introduction as histochemical tools. Anat Rec 298: 2051-2070, 2015.

55 García Caballero G, Kaltner H, Michalak M, Shilova N, Yegres M, André S, Ludwig AK, Manning JC, Schmidt S, Schnölzer M, Bovin NV, Reusch D, Kopitz J and Gabius H-J: Chicken GRIFIN: A homodimeric member of the galectin network with canonical properties and a unique expression profile. Biochimie 128-129: 34-47, 2016.

56 Kaltner H, García Caballero G, Sinowatz F, Schmidt S, Manning JC, André S and Gabius H-J: Galectin-related protein: an integral member of the network of chicken galectins. 2. From expression profiling to its immunocyto- and histochemical localization and application as tool for ligand detection. Biochim Biophys Acta 1860: 2298-2312, 2016.

57 Chen EY, Tan CM, Kou Y, Duan Q, Wang Z, Meirelles GV, Clark NR and Ma'ayan A: Enrichr: interactive and collaborative HTML5 gene list enrichment analysis tool. BMC Bioinformatics 14: 128, 2013.

Received March 25, 2017

Revised April 11, 2017

Accepted April 19, 2017 